"Iodouracil-mediated photo-cross-linking of DNA to EcoRII restriction endonuclease in catalytic conditions." Babkina, O.V., Chutko, C.A., Shashkov, A.A., Dzhiddzhoev, M.S., Eritja, R., Gromova, E.S. Photochem. \& Photobiol. Chem., 1(9), 636-640 (2002). doi: 10.1039/b20208a

\title{
Iodouracil-mediated photo-cross-linking of DNA to EcoRII restriction endonuclease in catalytic conditions
}

Olga V. Babkina ${ }^{a, b}$, Catherine A. Chutko ${ }^{c}$, Alexander A. Shashkov ${ }^{c}$, Murat S. Dzhidzhoev $^{c}$, Ramon Eritja ${ }^{d}$ and Elizaveta S. Gromova* ${ }^{a}$

${ }^{a}$ Department of Chemistry and Belozersky Institute of Physical and Chemical biology, Moscow State University, Moscow, 119992 Russia, e-mail: gromova@belozersky.msu.ru

${ }^{b}$ Engelhardt Institute of Molecular Biology, Russian Academy of Sciences, Moscow, 117984 Russia

${ }^{c}$ Department of Physics, Moscow State University, Moscow, 119992 Russia

${ }^{d}$ Centro de Investigación y Desarrollo, C.S.I.C., Jordi Girona 18-26, 08034 Barcelona

Corresponding author: E.S. Gromova, Department of Chemistry, Moscow State University, Moscow, 119992 Russia, e-mail: gromova@belozersky.msu.ru

\section{ABSTRACT}

We use a $\mathrm{XeCl}$ eximer laser with $50 \mathrm{~ns}$ pulses, a frequency of $0.3 \mathrm{~Hz}$ and a wavelength of $308 \mathrm{~nm}$ in appropriate conditions for the photocrosslinking of EcoRII restriction endonuclease to a 14-mer DNA duplex, containing a 5-iodo-2'-deoxyuridine residue (IdU). IdU replaced the thymidine residue within the EcoRII recognition sequence 5'-CCT/AGG. The binding of EcoRII endonuclease to IdU-containing DNA duplex was analyzed by gel retardation assay in the presence of $\mathrm{Ca}^{2+}$ or $\mathrm{Mg}^{2+}$ ions. Photocrosslinking of EcoRII to IdU-containing DNA duplex occurred only in a prereactive complex formed in the presence of $\mathrm{Ca}^{2+}$ ions. Photocrosslinking yields as a function of time and UV-laser light intensity were studied. 


\section{INTRODUCTION}

Type II restriction-modification systems (RMS) are common in bacteria, protecting cells from foreign DNA. One of the Escherichia coli RMS, EcoRII, includes endonuclease and DNA methyltransferase which recognize the DNA sequence ${ }^{\prime} \downarrow$ CCAA/TGG. Restriction endonuclease EcoRII cleaves DNA (cleavage site is indicated with an arrow) in the presence of $\mathrm{Mg}^{2+}$ ions and methyltransferase EcoRII methylates C5 of the internal cytosine (underlined) in the recognition site. Endonuclease EcoRII belongs to the type IIE restriction enzymes, which require binding to another recognition sequence for DNA cleavage ${ }^{1,2}$. Recently, the crystal structure of a type IIE restriction enzyme NaeI has been reported, ${ }^{3}$ but that of EcoRII is unknown. The reaction catalyzed by EcoRII shows positive substrate cooperativity ${ }^{4}$. The active EcoRII-substrate complex consists of two subunits of endonuclease interacting with two DNA recognition sites ${ }^{5}$. Depending on the substrate concentration, functional cooperativity can occur between two recognition sites on a single molecule (in cis) or between two sites from different DNA molecules (in trans) ${ }^{1}$. Transmission electron microscopy provided direct evidence that EcoRII mediates loop formation ${ }^{6}$. The identification of functional domains of EcoRII is at its very beginning. Recently, the sites of enzyme responsible for specific DNA-binding were determined by membrane-bound peptide repertoires ${ }^{7}$. However, EcoRII-DNA interface is not characterized, catalytic sites and their location in a dimeric enzyme are unknown. One of techniques for investigating a structure of enzyme-substrate complexes is photocross-linking of DNA to the associated protein $^{8}$. A 5-iodo-2'-deoxyuridine residue (IdU), which is "zero length" label is being incorporated into DNA to enhance photosensitivity ${ }^{8}$. A single substitution of IdU for dT does not appreciably disturb the protein-DNA complexes. The incorporation of IdU into nucleic acids and the use of high powered UV-lasers permit to obtain high photo-cross-linking yields providing adequate material for characterization ${ }^{9}$. Photoaffinity labeling of DNA methyltransferases with IdU-DNAs is widely used for determination of functionally important protein regions or/and amino acid residues ${ }^{10-12}$. Methyltransferases are usually photocrosslinked to their cognate IdU photolabel containing DNAs with high efficiency ${ }^{10-12}$. There are 
few reports on photoaffinity labeling of endonucleases by IdU-DNAs. Photocrosslinking of SsoII endonuclease to IdU-containing DNA via Trp61 by irradiation with helium/cadmium laser (325 nm) has been reported elsewhere ${ }^{13}$ Here, we used the light-induced photochemical crosslinking with a $\mathrm{XeCl}$ laser emitting at $308 \mathrm{~nm}$ to examine the covalent attachment of type IIE endonuclease EcoRII to IdUsubstituted DNA. Our long term goal is to determine the architecture of the EcoRII-DNA complex. The chemical crosslinking of EcoRII to DNA duplexes containing chemically active groups in the sugar-phosphate backbone has been reported elsewhere. ${ }^{14,15}$ Moreover, DNA duplex with a photoreactive aryl(trifluoromethyl)diazirine group has been tested for crosslinking to this enzyme. ${ }^{16}$.

\section{EXPERIMENTAL}

\section{Enzymes and oligonucleotides}

The restriction endonuclease EcoRII $(21 \mu \mathrm{M} /$ monomer, $200 \mathrm{U} / \mu \mathrm{l})$ was purified from Escherichia coli JM 109 cells carrying the isopropil- $\beta$-D-thiogalactopyranoside-inducible overexpression plasmid pQER15 which contained the ecoRIIR gene ${ }^{17}$. The EcoRII encoded by pQER15 plasmid possessed an terminal His ${ }_{6}$ affinity tail, making it possible to purify the enzyme by one-step Ni-chelate affinity column chromatography. One unit of restriction endonuclease activity was defined as the amound of enzyme that completely digested $1 \mu \mathrm{g}$ of $\lambda$ DNA at $37^{\circ} \mathrm{C}$ in $1 \mathrm{~h}$.

Oligonucleotides containing 5-halopyrimidines were synthesized as described elsewhere ${ }^{18}$. To avoid degradation of the 5-iodo- and 5-bromouracil and during deprotection, special phosphoramidites carrying the t-butylphenoxyacetyl group for the protection of the exocyclic amino group of the natural bases were used. These phosphoramidites allow to run the ammonia deprotection at room temperature where decomposition of 5-halopyrimidines is minimal. DNA

duplexes were ${ }^{32} \mathrm{P}$-labeled by T4 polynucleotide kinase (10 U/ $\mu 1$, Sintol, Russia) and $\left[\gamma-{ }^{32} \mathrm{P}\right]$-ATP (1000 Ci/mol, Izotop, Russia). 
Cleavage analysis of DNA duplexes by EcoRII was performed as described ${ }^{14}$.

\section{Gel mobility shift assay}

0.15-0.48 $\mu \mathrm{M}$ EcoRII was incubated with $0.5 \mu \mathrm{M}{ }^{32} \mathrm{P}$-labeled DNA duplexes I (hereafter concentrations of enzyme and DNA duplexes were calculated per monomer and per duplex, respectively) in $10 \mu \mathrm{l}$ of $40 \mathrm{mM}$ Tris- $\mathrm{HCl}$ buffer (pH 7.6), containing $50 \mathrm{mM} \mathrm{NaCl}, 7 \mathrm{mM}$ dithiotreitol (DTT), $8 \%$ glycerol (buffer A) and $10 \mathrm{mM} \mathrm{CaCl}_{2}$ or $5-10 \mathrm{mM} \mathrm{MgCl}_{2}$ for 10 min at $37^{\circ}$ $\mathrm{C}$ and $20 \mathrm{~min}$ on ice. The reactions were run for $3 \mathrm{~h}$ at $100 \mathrm{~V}$ on native $7.5 \%$ polyacrylamide gel (PAG). The gel was pre-run for $1 \mathrm{~h}$ at $100 \mathrm{~V}$. For authoradiography of the electrophoretic pattern, Kodak-XOMAT-S film was exposed at $4^{\circ} \mathrm{C}$ overnight.

\section{Photochemical cross-linking}

Photo-cross-linking reactions of EcoRII $(0.5$ or $0.7 \mu \mathrm{M})$ to DNA duplexes I $(0.5$ or $0.7 \mu \mathrm{M})$ or II $(0.7 \mu \mathrm{M})$ were performed in 10 or $500 \mu \mathrm{l}$ of $40 \mathrm{mM}$ Tris- $\mathrm{HCl}$ buffer (pH 7.6), containing 50 $\mathrm{mM} \mathrm{NaCl}$ and $7 \mathrm{mM}$ DTT (buffer B) in the presence or in the absence of $10 \mathrm{mM} \mathrm{CaCl}_{2}$. Reaction mixtures were preincubated for $10 \mathrm{~min}$ at $37^{\circ} \mathrm{C}$ and $20 \mathrm{~min}$ on ice. Photo-cross-linking was induced

with a $\mathrm{XeCl}$ eximer laser ${ }^{22}$ operating at $308 \mathrm{~nm}$, pulse duration $50 \mathrm{~ns}$, repetition rate $0.3 \mathrm{~Hz}$, pulse energy $20 \mathrm{~mJ}$ and beam diameter $4 \mathrm{~cm}$. Reactions were conducted in $0.5 \mathrm{ml}$ micro test tubes containing $10 \mu \mathrm{l}$ aliquots or in quartz cuvette $(10.5 \mathrm{~cm})$ containing $500 \mu$ l aliquots on ice for 1.3-40 min. To vary of the laser intensity probes were settled at different distances from the focal point of the collecting lens (f $2 \mathrm{~m}$ ). Reactions were analyzed by $12 \%$ SDS-PAGE. Gels were analyzed by authoradiography or by Coomassie blue staining followed by authoradiography. The cross-linking yields were determined as the ratio of the covalent conjugate radioactivity to the total radioactivity of conjugate and unbound oligonucleotide. Radioactivity of gel slices was determined by Cherenkov counting.

\section{Ultraviolet light-induced degradation of 5-iodo-2'-deoxyuridine}

Aqueous solutions of $1.5 \mathrm{M} \mathrm{IdU}(0.1 \mathrm{ml})$ were placed into the $1.5 \mathrm{ml}$ micro test tubes and 
irradiated at intensity of $5 \times 10^{5} \mathrm{~W} / \mathrm{cm}^{2}$ or $1 \times 10^{7} \mathrm{~W} / \mathrm{cm}^{2}$. After $10-30 \mathrm{~min}$ of irradiation solutions were diluted tenfold with water. Absorption spectra were obtained using a Hitachi 150-20 spectrophotometer (Japan).

\section{RESULTS AND DISCUSSION}

\section{Binding of R•EcoRII to IdU-substituted DNA duplex}

We use a 14-mer DNA duplex I, in which dT within the recognition sequence of EcoRII (CCA/TGG) was replaced by a photo-label IdU as a reagent for photo-cross-linking to EcoRII.

5'GCCAACCXGGCTCT 3' 3'CGGTTGGACCGAGA 5'
(I), where $\mathrm{X}=\mathrm{IdU}$

The substrate properties of modified DNA and its ability to specifically bind to EcoRII were examined. It was found that introduction of IdU into the center of EcoRII recognition site does not abolish activity of the enzyme (data not shown). In the absence of $\mathrm{Mg}^{2+}$ ions, the canonical substrate formed two complexes with EcoRII characterized by specific electrophoretic mobilities as revealed by gel retardation assay ${ }^{20}$. Addition of $\mathrm{Mg}^{2+}$ ions resulted in disappearance of the "lower" complex and led to accumulation of the "upper" complex. At catalytic $\mathrm{Mg}^{2+}$ ions concentration $(5-10 \mathrm{mM})$ only "upper" complex was formed ${ }^{21}$ (O.V. Petrauskene and E.S. Gromova, unpublished data). We carry out photocrosslinking experiments with IdU-DNA duplex I in the conditions of the formation of one type of complexes, an "upper" one. However, in the presence of $\mathrm{Mg}^{2+}$ ions this duplex was cleaved, therefore the use of $\mathrm{Ca}^{2+}$ ions, which are cofactor analog, seems reasonable. $\mathrm{Ca}^{2+}$ ions do not behave as a cofactor of restriction enzymes but replace $\mathrm{Mg}^{2+}$ ions in the enzyme catalytic center and thereby to inhibit hydrolysis ${ }^{22}$. EcoRII does not cleave the canonical 14-mer substrate with one recognition site in the presence of $\mathrm{Ca}^{2+17}$. To study formation of IdU-substituted DNA - EcoRII complex with $\mathrm{Ca}^{2+}$ ions, a gel mobility shift experiment was performed (Fig.1). In the range of DNA/EcoRII monomer molar ratio 3:1-1:1 one type of complexes was formed (Fig.1, lanes 1-5). In the presence of $5 \mathrm{mM} \mathrm{Mg}^{2+}$ ions (lanes 6-7) and $10 \mathrm{mM} \mathrm{Mg}^{2+}$ (lanes 8-9) one can see IdU-DNA duplex I - enzyme complexes, traces of starting IdU DNA duplexes and products of their cleavage 
by EcoRII. The electrophoretic mobilities of IdU-substituted DNA-EcoRII-Ca ${ }^{2+}$ complexes (lanes 15) are the same as those of (IdU-DNA)-EcoRII- $\mathrm{Mg}^{2+}$ complexes (lanes 6-9). Thus, the complex of IdU-substituted DNA with EcoRII in the presence of $\mathrm{Ca}^{2+}$ ions is a pre-reactive one and consists of dimeric EcoRII and two IdU-DNA duplexes.

\section{Formation of the photo-cross-linked EcoRII-DNA complex}

We used a $\mathrm{XeCl}$ eximer laser, which is a powerful source of monochromatic light (308 nm) with 50 ns pulses and frequency of $0.3 \mathrm{~Hz}{ }^{19}$ for photocrosslinking of EcoRII to 14-mer IdU-containing DNA. The $308 \mathrm{~nm}$-emitting $\mathrm{XeCl}$ eximer laser with other parameters has been used previously in protein-RNA ${ }^{23}$ and protein-DNA ${ }^{24,25}$ cross-linking.

UV cross-linking. The ${ }^{32} \mathrm{P}-$ labeled DNA duplex containing IdU for dT substitution in the recognition site was irradiated with 308-nm monochromatic light in the presence of EcoRII and $\mathrm{Ca}^{2+}$ ions, the DNA/enzyme ratio being $~ 1: 1$, i.e. under conditions when only one type of enzymesubstrate complex was formed (Fig.1, lane 5). Aliquots of reaction mixtures were analyzed by denaturig polyacrylamide gel electrophoresis (PAGE). Irradiation of IdU DNA-EcoRII-Ca ${ }^{2+}$ complex resulted in formation of only one product migrating in gel more slowly as compared to free ${ }^{32} \mathrm{P}-$ labeled oligonucleotide (Fig.2A). This band representing a cross-linked EcoRII-DNA complex was observed both on the Coomassie blue stained gel and on autoradiogram. We failed to obtain EcoRII-DNA crosslink without $\mathrm{Ca}^{2+}$ ions (Fig.2A).

The formation of a crosslink in the presence of $\mathrm{Ca}^{2+}$ suggests that cross-linking occurs at the catalytic step. A conformational transition of the enzyme may occur in the presence of $\mathrm{Ca}^{2+}$ ions thus bringing an amino acid residue of EcoRII closer to IdU of the central base pair of EcoRII recognition site in DNA. As a result, the iodouracil residue and the amino acid residue took a suitable orientation that favored crosslinking. In the case of chemical crosslinking of EcoRII to DNA duplex containing monosubstituted pyrophosphate internucleotide bond crosslinking yields strongly depended on $\mathrm{Mg}^{2+}$ concentration, supporting the conformational transition of EcoRII ${ }^{15}$. 
When instead of IdU 5-bromo-2'-deoxyuridine residue (BdU) was introduced into the center of the EcoRII recognition site, the yield of EcoRII-DNA cross-link in the presence of $\mathrm{Ca}^{2+}$ dramatically reduced (Fig.2B). This experiment was performed at intensity $\sim 1 \times 10^{6} \mathrm{~W} / \mathrm{cm}^{2}$. The difference in the cross-linking efficiency with IdU- and BdU-containing 14-mer DNAs may be due to the higher absorption of the IdU chromophore at $308 \mathrm{~nm}$ and the excellent leaving group reactivity of iodide ${ }^{8,9}$.

Photocrosslinking as a function of laser light intensity. To improve efficiency of covalent attachment of EcoRII to IdU-substituted DNA duplex, the time courses of the cross-linking reaction at different laser light intensities were monitored (Fig.3A and B). All experiments were performed in the presence of $\mathrm{Ca}^{2+}$ ions. A lot of products were formed upon irradiation of DNA-enzyme complex with high-intensity laser light $\left(\sim 1.5 \times 10^{7} \mathrm{~W} / \mathrm{cm}^{2}\right)$ during 10-30 min. Photocrosslinking yields decreased with the time of irradiation. Products moving on the gel faster than the EcoRIIDNA covalent complex were observed (Fig. 3A). When the irradiation intensity was reduced to $\sim 1 \times 10^{6} \mathrm{~W} / \mathrm{cm}^{2}$, the number of undesirable products of photodamage diminished (Fig. 3A). The yield of EcoRII-DNA crosslink increased with time and leveled off at $20 \%$ in 9 min of irradiation.

only one band representing a crosslinked complex was observed, both on the Coomassie blue stained gel and on autoradiogram, when the laser operated at $\sim 5 \times 10^{5} \mathrm{~W} / \mathrm{cm}^{2}$ (Fig. 3A). However, in this case longer incubation times were necessary to achieve $\sim 11 \%$ crosslinking of total DNA to EcoRII. It is noteworthy that crosslinking experiments were performed at DNAEcoRII monomer molar ratio $\sim 1: 1$ to have stoichiometry of the active DNA-enzyme complex. ${ }^{5}$ However, in these conditions only part of total DNA was bound to the enzyme (Fig. 1, lane 5). Hence, the resulting crosslinking yields calculated relatively to bound DNA should be larger. It should be noted that the mechanism of photodecomposition of 5-iodo-2'-deoxyuridine in aqueous solution depends on laser light intensity (Fig. 4). Irradiation at different intensities resulted in progressive loss of the characteristic absorption peak near $280 \mathrm{~nm}$. After $30 \mathrm{~min}$ of irradiation at $\sim 1.5 \times 10^{7} \mathrm{~W} \mathrm{~cm}^{-2}$ (Fig. 4B, curve 3) the photoproduct shows a peak near $260 \mathrm{~nm}$ which is 
characteristic of the absorption spectrum of 2'-deoxyuridine. At $\sim 1.5 \times 10^{5} \mathrm{~W} \mathrm{~cm}^{-2}$ the loss of absorbance of IdU at $\sim 280 \mathrm{~nm}$ was not accompanied by the appearance of a peak at $260 \mathrm{~nm}$ (Fig. $4 \mathrm{~A}$, curve 3). This result probably fits the photodimerization of dU monomers in solution. ${ }^{26}$

The formation of photodamage products at laser intensities higher than $\sim 5 \times 10^{5} \mathrm{~W} / \mathrm{cm}^{2}$ may be mainly due to protein photodegradation as it follows from mobilities of degradation products in the gel (Fig.3), in agreement with the available data on enzyme-DNA complexes irradiated at 308 $\mathrm{nm}^{9,10}$. The mechanism of protein photodamage at intensities higher than $\sim 5 \times 10^{5} \mathrm{~W} / \mathrm{cm}^{2}$ is apparently associated with absorption of additional quantum by preexcited Trp residues owing to high laser intensities. The sum of energies of two $308 \mathrm{~nm}$ photons is about $8 \mathrm{eV}$, which is enough for a Trp excited electron to be expelled from the protein. Thus, the protein converts into a very reactive ion radical and may thus give rise to photodamage conversions. Accordingly, the decrease of intensity to $\sim 1.5 \times 10^{5} \mathrm{~W} / \mathrm{cm}^{2}$ allowed us to avoid the photodamage of the enzyme (Fig. 3A, right window). The correlation between the intensity of Nd-YAG laser $(266 \mathrm{~nm})$ irradiation and the degradation of nucleic acid in the DNA-protein complex has been described elsewhere and attributed to biphotonic excitation by high intensity pulsed lasers. ${ }^{8}$

At intensities higher than $\sim 1.5 \times 10^{5} \mathrm{~W} \mathrm{~cm}^{-2}$ (for example, at $\sim 1.0 \times 10^{6} \mathrm{~W} \mathrm{~cm}^{-2}$ ), degradation occurred at 2 min of irradiation (Fig. 3A). Similar results have been reported for the methylase EcoRI-(IdU-DNA) complex. ${ }^{10} \mathrm{Here}$, at $\sim 1.5 \times 10^{5} \mathrm{~W} \mathrm{~cm}^{-2}$, even at $30 \mathrm{~min}$ of exposure, we did not detect degradation of the crosslinked complex.

Photocrosslinking reaction yields as a function of laser light intensity at the fixed dose of energy were examined. We increased irradiation time as the intensity decreased. The data were fitted to an exponential decay function, revealing that photocrosslinking yields dramatically depend on laser light intensity (Fig. 5).

Thus, we established the conditions for the photoaffinity modification of EcoRII by IdUsubstituted DNA with $\mathrm{XeCl}$ laser (308 nm) avoiding protein and DNA degradation. 


\section{CONCLUSIONS}

The 308 nm-emitting XeCl excimer laser induced crosslinking of EcoRII to DNA-duplex containing IdU in the center of EcoRII recognition site in catalytic conditions, i.e. in the presence of $\mathrm{Ca}^{2+}$ as substitute for the natural cofactor, $\mathrm{Mg}^{2+}$, indicating a close proximity between the protein and the central thymine base in the recognition site of the catalytic EcoRII-DNA complex. Crosslinking yields strongly depend on the laser light intensity. Yield $(\sim 11 \%)$ was maximal at $\sim 5 \times 10^{5}$ $\mathrm{W} / \mathrm{cm}^{2}$ during $30 \mathrm{~min}$. In these conditions biopolymers did not show photodamage.

\section{ACNOWLEDGMENTS}

We thank Professor Alexander Yu. Borisov for valuable discussions and Robin Rycroft for assistance in preparation of the manuscript. We are grateful to Professor Ashok Bhagwat for providing us with the pR224 plasmid containing the ecoRII gene. This study was supported by the Russian Foundation of Fundamental Investigation (project no. 01-04-48637). 


\section{REFERENCES}

1 D.H. Krueger, D. Kupper, A. Meisel, M. Reuter and C. Schroeder, The significance of distance and orientation of restriction endonuclease recognition sites in viral DNA genomes, FEMS Microbiol. Rev., 1995, 17, 177-184.

2 A. Pingoud and A. Jeltsch, Structure and function of type II restriction endonucleases, Nucleic Acids Res., 2001, 29, 3705-3727

3 Q. Huai, J.D. Colandene, Y. Chen, F. Luo, Y. Zhao, M.D. Topal and H. Ke, Crystal structure of NaeI-an evolutionary bridge between DNA endonuclease and topoisomerase, EMBO J., 2000, 19, 3110-3118.

4 S. Gabbara and A.S. Bhagwat, Interaction of EcoRII endonuclease with DNA substrates containing single recognition sites, J. Biol. Chem., 1992, 267, 18623-18630.

5 O.V. Petrauskene, E.A. Karpova, E.S. Gromova and W. Guschlbauer, Two subunits of EcoRII restriction endonuclease interact with two DNA recognition sites, Biochem. Biophys. Res. Commun., $1994,198,885-890$.

6 M. Mucke, R. Lurz, P. Mackeldanz, J. Behlke, D.H. Krueger and M. Reuter, Imaging DNA loops induced by restriction endonuclease EcoRII. A single amino acid substitution uncouples target recognition from cooperative DNA interaction and cleavage, J. Biol. Chem., 2000, 275, 3063130637.

7 M. Reuter, J. Schneider-Mergener, D. Kupper, A. Meisel, P. Mackeldanz, D.H. Krueger and C. Schroeder, Regions of endonuclease EcoRII involved in DNA target recognition identified by membrane-bound peptide repertoires, J. Biol. Chem., 1999, 274, 5213-5221.

8 K.M. Meisenheimer and T.H. Koch, Photo-cross-linking of nucleic acids to associated proteins, Crit. Rev. Biochem. Mol. Biol, 1997, 32, 101-140.

9 M.C. Willis, B.J. Hicke, O.C. Uhlenbeck, Th.R. Cech and T.H. Koch, Photocrosslinking of 5iodouracil-substituted RNA and DNA to proteins, Science, 1993, 262, 1255-1257. 
10 D.L. Wong, J.G. Pavlovich and N.O. Reich, Electrospray ionization mass spectrometric characterization of photocrosslinked DNA-EcoRI DNA methyltransferase complexes, Nucleic Acids Res., 1998, 26, 645-649.

11 B. Holz, N. Dank, J.E. Eickhoff, G. Lipps, G. Krauss and E. Weinhold, Identification of the binding site for the extrahelical target base in $\mathrm{N}^{6}$-adenine DNA methyltransferases by photo-crosslinking with duplex oligodeoxyribonucleotides containing 5-iodouracil at the target position, J. Biol. Chem., 1999, 274, 15066-15072.

12 D.L. Wong and N.O. Reich, Identification of tyrosine 204 as the photo-cross-linking site in the DNA-EcoRI DNA methyltransferase complex by electrospray ionization mass spectrometry, Biochemistry, 2000, 39, 15410-15417.

13 E.A. Kubareva, H. Thole, A.S. Karyagina, T.S. Oretskaya, A. Pingoud and V. Pingoud, Identification of a base-specific contact between the restriction endonuclease SsoII and its recognition sequence by photo-cross-linking, Nucleic Acids Res., 2000, 28, 1085-1091. 14 M.G. Brevnov, O.M. Gritsenko, S.N. Mikhailov, E.V. Efimtseva, B.S. Ermolinsky, A. Van Aerschot, P. Herdewijn, A.V. Repyk and E.S. Gromova, DNA duplexes with reactive dialdehyde groups as novel reagents for cross-linking to restriction-modification enzymes, Nucleic Acids Res., 1997, 25, 3302-3309.

15 G.Ya. Sheflyan, E.A. Kubareva, E.M. Volkov, T.S. Oretskaya, E.S. Gromova and Z.A. Shabarova, Chemical cross-linking of $M v a \mathrm{I}$ and EcoRII enzymes to DNA duplexes containing monosubstituted pyrophosphate internucleotide bond, Gene, 1995, 157, 187-190.

16 A.N. Topin, O.M. Gritsenko, M.G. Brevnov, E.S. Gromova and G.A. Korshunova, Synthesis of a new photo-cross-linking nucleoside analogue, containing aryl(trifluoromethyl)diazirine group: application for EcoRII and MvaI restriction-modification enzymes, Nucleosides \& Nucleotides, $1998,17,1163-1175$.

17 O. V. Babkina, A. G. Evstafieva, N. V. Chichkova, A. B. Vartapetian, S. Mueller, V. B. Baskunov, O. V. petrauskene, S. N. kochetkov and E. S. Gromova, Recombinant components of the 
EcoRII restriction-modification system: restriction endonuclease can interact with DNA $\bullet$ RNA duplexes, Mol. Biol. (Russ.), 2000, 34, 913-920.

18 E. Ferrer, M. Wiersma, B. Kazimierczak, Ch.W. Mueller and R. Eritja, Preparation and properties of oligodeoxynucleotides containing 5-iodouracil and 5-bromo- and 5-iodocytosine, Bioconjugate Chem., 1997, 8, 757-761.

19. M.S. Dzhidzhoev, V.T. Platonenko and V.K. Popov, A high power XeCl excimer discharge laser with high stability over time and a short response time, Moscow University physics bulletin (Engl. Transl.), 1984, 39, 118-120.

20 E.A. Karpova, E.A. Kubareva, E.S. Gromova and Ya.I. Buryanov, Peculiarities of the restriction endonuclease EcoRII to synthetic DNA duplexes. Biochem. Mol. Biol. Int., 1993, 29, 113-121.

21 E.A. Karpova, E.A. Kubareva and Z.A. Shabarova, A model of EcoRII restriction endonuclease action: the active complex is most likely formed by one protein subunit and one DNA recognition site, IUBMB Life, 1999, 48, 91-98.

$22 \mathrm{H}$. Viadiu and A.K. Aggarwal, The role of metals in catalysis by the restriction endonuclease BamHI, Nature Struct. Biol.,1998, 5, 910-916.

23 M.C. Willis, K.A. LeCuyer, K.M. Meisenheimer, O.C. Uhlenbeck and T.H. Koch, An RNAprotein contact determined by 5-bromouridine substitution, photocrosslinking and sequencing, Nucleic Acids Res., 1994, 22, 4947-4952.

24 B.J. Hicke, M.C. Willis, T.H. Koch and Th.R. Cech, Telomeric protein-DNA point contacts identified by photo-cross-linking using 5-bromodeoxyuridine, Biochemistry, 1994, 33, 3364-3373. 25 M.C. Golden, K.A. Resing, B.D. Collins, M.C.Willis and T.H. Koch, Mass spectral characterization of a protein-nucleic acid photocrosslink, Protein Science, 1999, 8, 2806-2812. 26 G. J. Fisher and H. E. Johns, in Photochemistry and photobiology of nucleic acids, ed. S. Y. Wang, Academic Press, New York, San Francisco, London, 1976, p. 169. 


\section{FIGURES}

Fig. 1. Binding of EcoRII to IdU-containing DNA duplex I in the presence of $\mathrm{Ca}^{2+}$ or $\mathrm{Mg}^{2+}$ ions.

Autoradiogram of $7.5 \%$ non-denaturing PAG. The binding reactions contained $0.5 \mu \mathrm{M}{ }^{32} \mathrm{P}$-labeled

DNA, EcoRII with indicated concentrations $(0.15-0.48 \mu \mathrm{M})$, buffer A and indicated concentrations of $\mathrm{CaCl}_{2}$ or $\mathrm{MgCl}_{2}$.

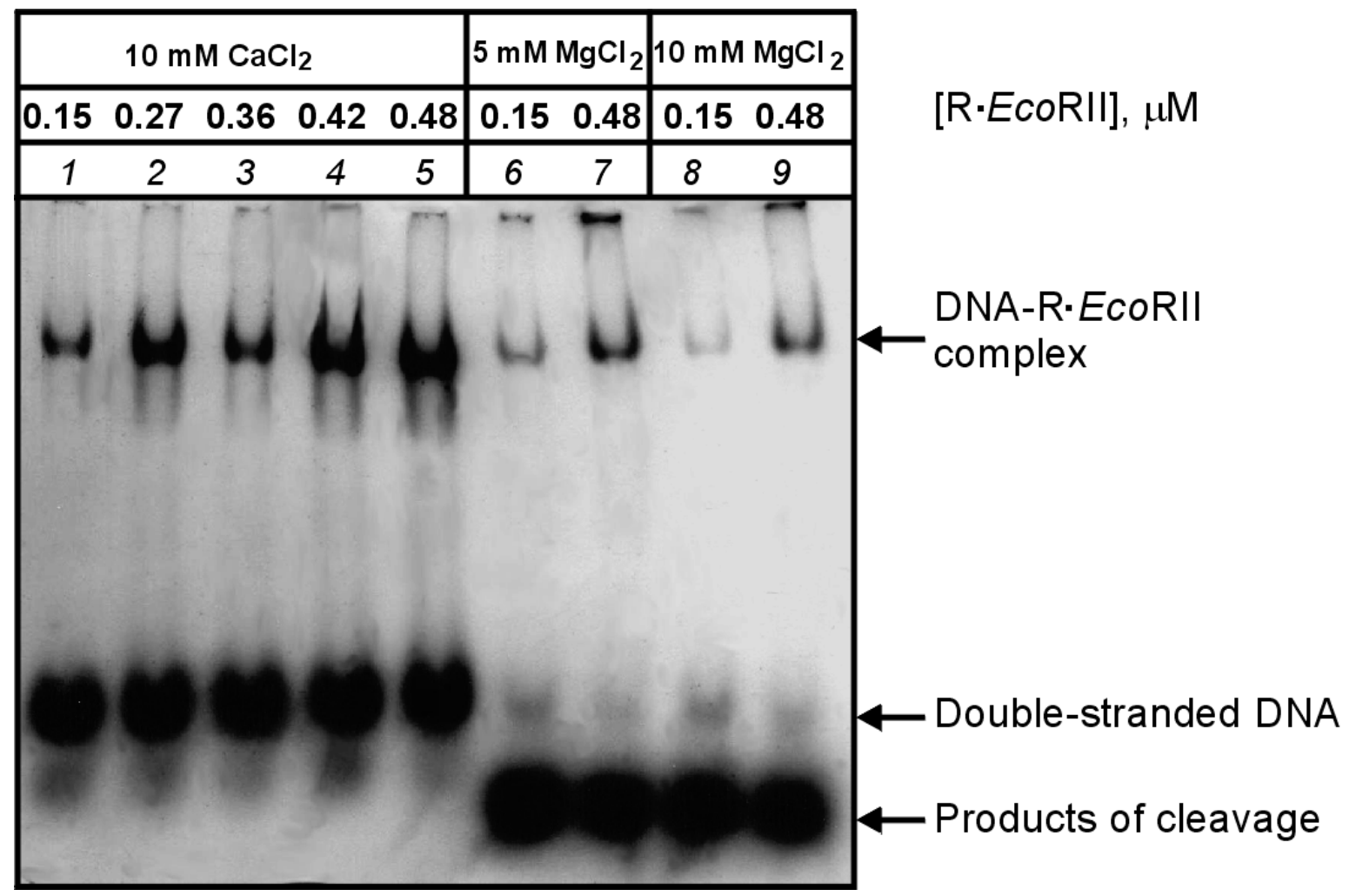


Fig. 2. Photo-cross-linking of EcoRII to DNA-duplexes containing IdU (I) or BdU (II) in the center of EcoRII recognition site at $308 \mathrm{~nm}$. Products were separated by $12 \%$ SDS-PAGE. A, $0.5 \mu \mathrm{M}^{32} \mathrm{P}-$ labeled DNA duplex I and $0.7 \mu \mathrm{M}$ of EcoRII in the presence (lane 3) or in the absence (lane 2) of $10 \mathrm{mM} \mathrm{CaCl}_{2}$ after irradiation. Lane $1:{ }^{32} \mathrm{P}$-labeled DNA-duplex I. B, $0.7 \mu \mathrm{M}^{32} \mathrm{P}$-labeled DNAduplexes I (lane 1 ) or II (lane 2 ) and $0.7 \mu \mathrm{M}$ EcoRII in the presence of $10 \mathrm{mM} \mathrm{CaCl}_{2}$ after irradiation. DNA-duplex II:

5'GCCAACCXGGCTCT 3' 3'CGGTTGGACCGAGA 5', where $\mathrm{X}=\mathrm{BdU}$

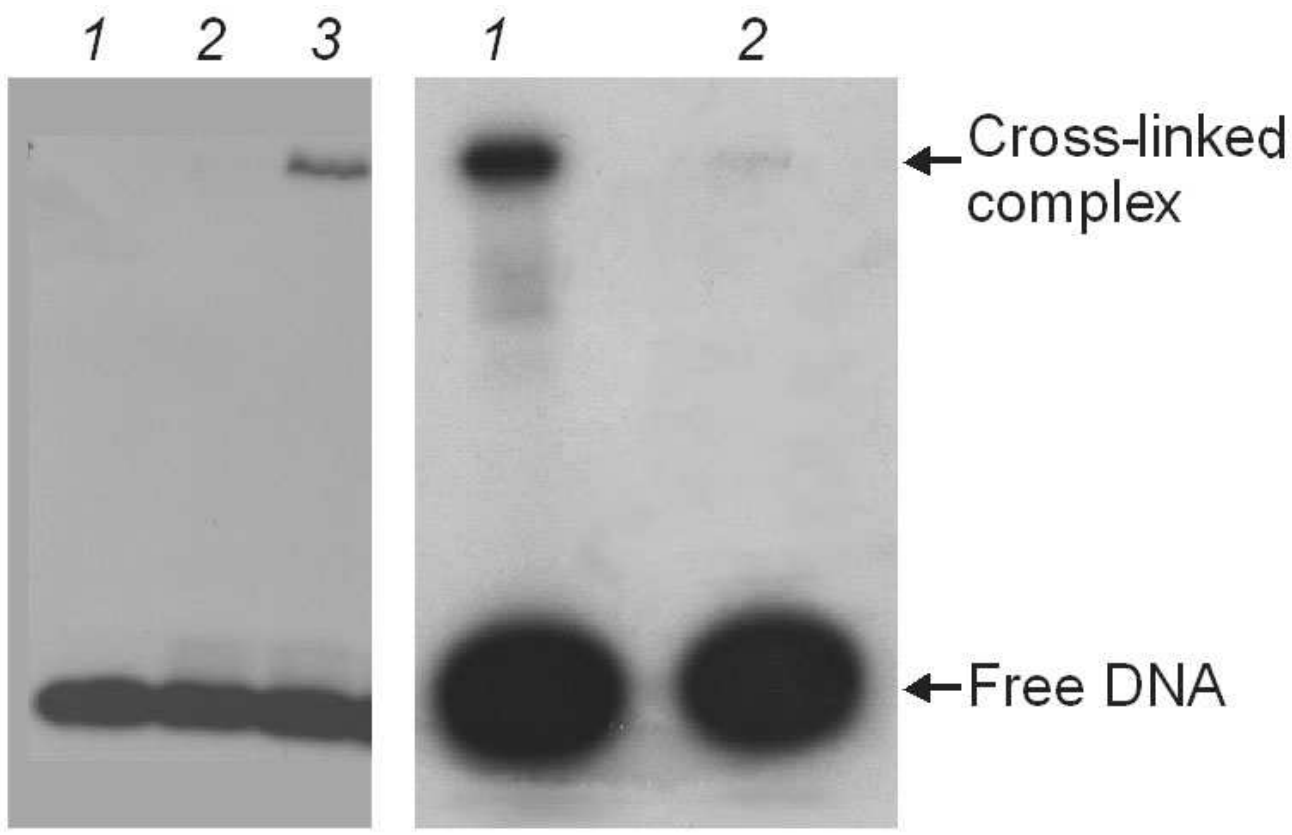


Fig. 3. Photocrosslinking of EcoRII to IdU-DNA duplex I as a function of irradiation time at different laser light intensities. $\boldsymbol{A}$, autoradiograms of $12 \%$ SDS-PAGE displaying products after irradiation of reaction mixture containing $0.5 \mu \mathrm{M}^{32} \mathrm{P}$-labeled DNA-duplex I and $0.5 \mu \mathrm{M}$ EcoRII in buffer $\mathrm{B}$ in the presence of $10 \mathrm{mM} \mathrm{CaCl}_{2}$ at $308 \mathrm{~nm}$. Irradiation times, light intensities (I) and photocrosslinking yields are indicated. $\boldsymbol{B}$, photocrosslinking yields as a function of reaction times at corresponding intensities.

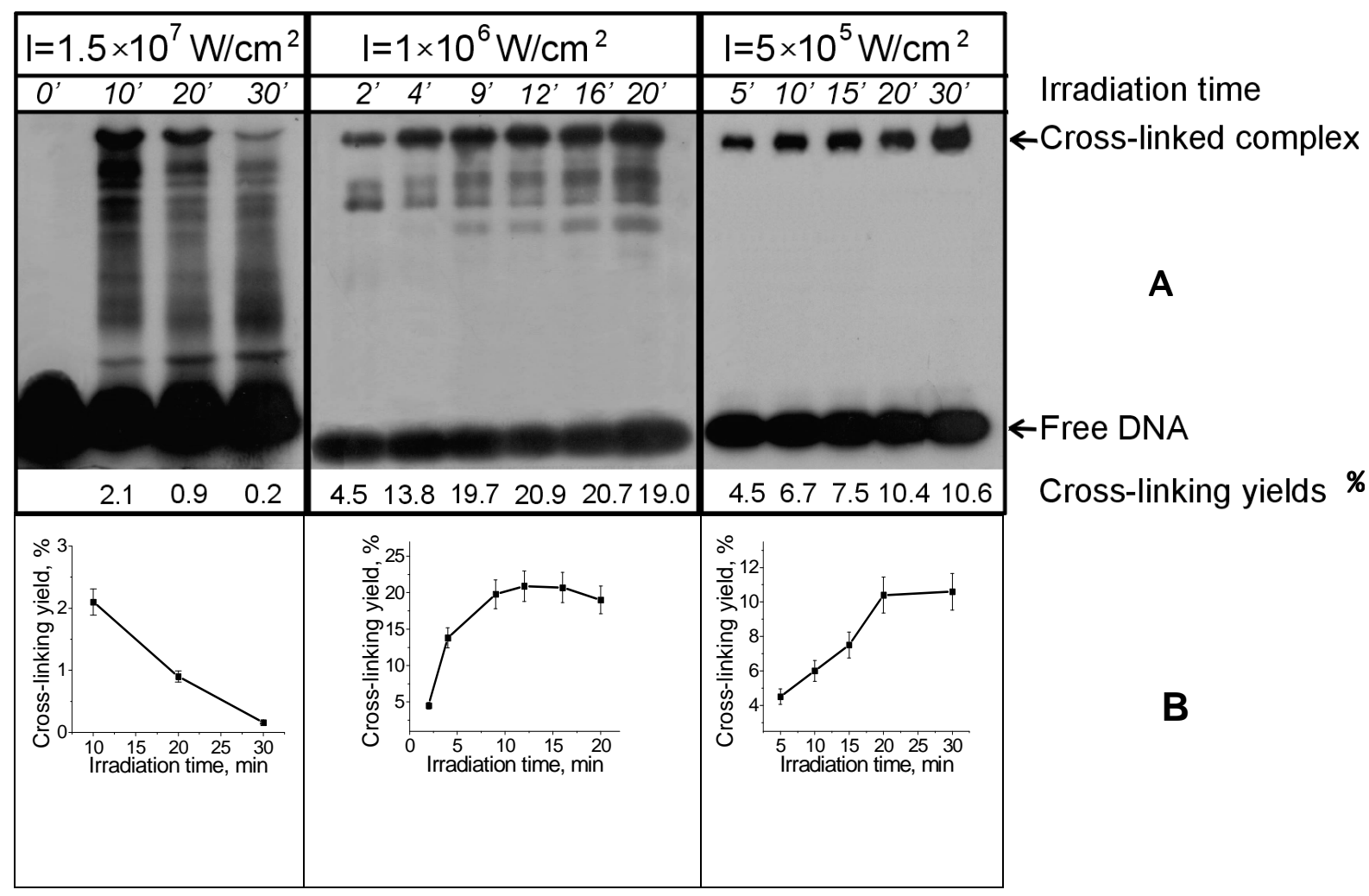


Fig. 4 UV-absorption spectra of 0.15 M 5-iodo-2'-deoxyuridine in aqueous solution without irradiation or after irradiation with UV laser light. Spectra 1(-)-without irradiation; spectra $2(\cdots)$ and spectra 3 (---)-irradiation for 15 and 30 min, respectively. Laser light intensities were $5 \times 10^{5}$ $\mathrm{W} / \mathrm{cm}^{2}(\boldsymbol{A})$ or $1 \times 10^{7} \mathrm{~W} / \mathrm{cm}^{2}(\boldsymbol{B})$.

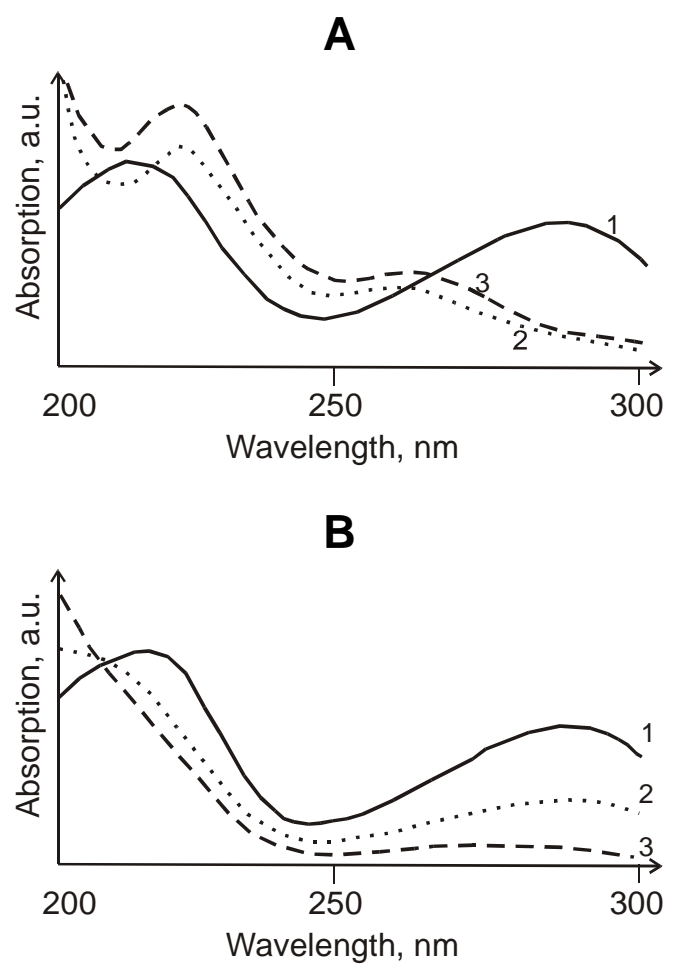


Fig. 5. Dependence of photo-cross-linking of EcoRII to IdU-DNA duplex I on laser light intensity at dose absorbed kept constant. $0.5 \mu \mathrm{M}{ }^{32} \mathrm{P}$-labeled DNA-duplex I and $0.5 \mu \mathrm{M}$ EcoRII were irradiated at $308 \mathrm{~nm}$ for $1.3,2.5,5.0,10$ and $40 \mathrm{~min}$ at intensities $3.6 \times 10^{6}, 1.8 \times 10^{6}, 1 \times 10^{6}$ and $0.12 \times 10^{6} \mathrm{~W} / \mathrm{cm}^{2}$ respectively in buffer $\mathrm{B}$ in the presence of $10 \mathrm{mM} \mathrm{CaCl}_{2}$.

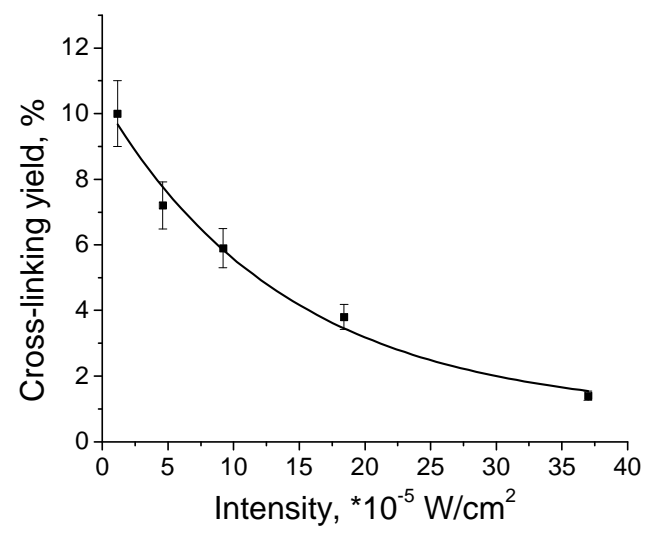

